\title{
陳旧性心筋梗塞におけ子致死性不整脈の発生予知に関 する心室再分極過程不均一性評価法による検討
}

仁禮 隆*1 笠貫 宏*2

陳旧性心筋梗塞における体表面 QRST 等積分值図, recovery time dispersion (RTd)およびQT dispersion(QTd) の致死的不整脈発生予知に関する有用性につい て検討した，陳旧性前壁心筋梗塞 166 例に対して体表面 87 単極誘導心電図および 標準 12 誘導心電図同時記録を行つた，QRST 等積分值図作成，87 誘導RTdおよ び標準 12 誘導 QTd 計測を行い，心拍数補正した (RTcd，QTcd)。追跡調查を 72 力 月行いKaplan-Meier 法にて検討した. 72 力月後の持続性心室頻拍または突然死 からの累積回避率は，QRST 等積分値図; 単一双極子性 $98.9 \%$, 多双極子性 $78.8 \%(p<0.001), R T c d ； 180 \mathrm{~ms}$ 末満 $96.4 \%, 180 \mathrm{~ms}$ 以上 $54.7 \%(p<$ 0.001), QTcd； 80ms未満 92.9\%,80ms以上 $86.1 \%$ (n.s.)であつた. 診断 精度は, QRST等積分値図；感度 $92.9 \%$ ，特異度 $65.1 \%, R T c d ；$ 感度 $71.4 \%$ ， 特異度 $89.5 \%$, QTcd ; 感度 $50.0 \%$ ，特異度 $68.4 \%$ あ゙あた。 以上より，陳旧 性前壁心筋梗塞における致死的不整脈発生予知に関して QRST 等積分值図および RTcdが有用であることが示唆された.（心電図, 2003；23：313～322）

\begin{tabular}{|ll|}
\hline Keywords & $\bullet$ 体表面電位図 \\
& $\bullet$ dispersion \\
& $\bullet$ 心室頻拍 \\
& $\bullet$ 突然死 \\
& $\bullet$ 心筋梗塞 \\
\hline
\end{tabular}

*1都立荏原病院循環器科

（₹ 145-0065 東京都大田区東雪谷4-5-10）

*2東京女子医科大学附属日本心臓血圧研究所循環器内科

\section{I.はじめに}

近年，持続性心室頻拍および心室細動などの致死 的心室性不整脈に対する塩酸アミオダロンおよび植 込み型除細動器による治療が確立し, 生命予後を改 善させることが可能となった.このような状況にお いて致死的不整脈のハイリスク患者をいかに漏れる ことなく見い出すかが, 今日の心電学的検査法の大 きな課題となっている.

心筋梗塞後における致死的不整脈発生予知に関す

Efficacy of assessing methods for the disparity of the ventricular repolarization in patients with old myocardial infarction Takashi Nirei, Hiroshi Kasanuki 


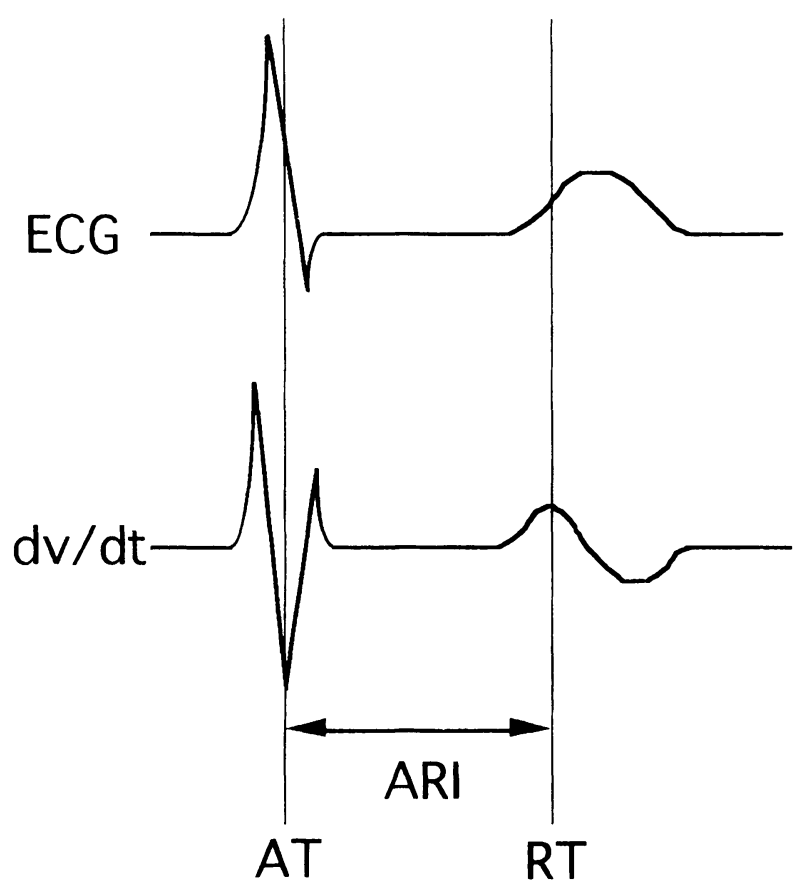

図1 Recovery time と activation-recovery interval $\mathrm{dv} / \mathrm{dt}$ : 単極誘導心電図一次微分値, AT : activation time, RT : recovery time, ARI : activation-recovery interval

る非観血的評価法としては, 心室頻拍の基質の存在 を診断する心室遅延電位 ${ }^{11}$, 再分極過程の不均一性 増大を評価する QT dispersion ${ }^{213}$, , recovery time

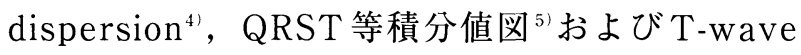
alternans $^{61,7)}$, さらにはホルター心電図 ${ }^{81,9)}$, 左室駆 出率 $(\mathrm{LVEF})^{9)}$ などが知られている.

QT dispersionは, 再分極過程の終了時間のばら つきをすべての誘導における T波終末の最長点と最 短点の差として評価, 検討する検査法である，標準 12 誘導心電図を利用できることおよび計測が簡便で あることなどの理由で広く普及しているが，方法論 的に限界があることが知られている ${ }^{10)}$.

Recovery time $(\mathrm{RT})$ は単極誘導心電図上, T波一次 微分值が最大となる時点のことであり, 活動電位第 3 相の最小 $\mathrm{dv} / \mathrm{dt}$ 点とよく相関し局所の心外膜面心筋再 分極過程終了時点に対応するとされている ${ }^{11)}$ (図1). QRS 波一次微分值が最小となる時点(activation time) からRTまでの時間を activation-recovery interval (ARI) といい, 局所の心外膜面心筋の不応期および
活動電位持続時間とよく相関する ${ }^{12)}{ }^{13)}$. シミュレー ションおよび手術例の検討より，心表面の ARI分布 を体表面心電図から推定可能であることが報告され ている ${ }^{14), 15)}$. 体表面心電図において dispersionの概 念を用いて再分極過程不均一性を検討する場合に は，終了時点のばらつきを検討する目的でARIより も RTが用いられることが多い.この理由として， 心電図上QS 波を有する心筋梗塞および拡張型心筋 症などの疾患においてはactivation timeの計測が困 難なことがあげられる。 また，RT dispersionの算 出の際に全誘導における最早期 $\mathrm{QRS}$ 波開始点を基準 としてRTを計測することは，QT dispersionの算出 において全誘導における最早期 $\mathrm{QRS}$ 波開始点から 個々の誘導の T波終末までの時間の最大值と最小值 との差より求めることと合致する ${ }^{16), 17)}$. RTの計測 はコンピュータを使用し, 計測方法も確立しており RT dispersionの再現性は高い.

QRST等積分值図は, 多誘導点における ventricular gradientを2次元的に表示したものであ る. 局所の再分極異常について検討可能であり，再 分極過程評価法として臨床的有用性が認められてい $3^{18 i 21)}$. 再分極過程不均一性に関しては通常は単一 双極子性分布であるが，不均一性が増大している場 合には多双極子性分布として表現される。

心筋梗塞後における追跡調查による再分極過程不 均一性評価法の有用性に関する報告は少なく, RT dispersion およびQRST等積分值図に関しては皆無 である ${ }^{7,}$ 22), 23). 本研究の目的は, 陳旧性心筋梗塞患 者において長期追跡調査を行いQT dispersion, RT dispersion およびQRST 等積分值図の 3 法の有用性 について検討することである.

\section{II. 対 象}

対象は, 東京女子医科大学附属日本心臓血圧研究 所循環器内科に 1989 年 6 月から 1999 年 10 月までの 間に入院し体表面電位図記録を施行した陳旧性前壁 心筋梗塞 166 例, 男 148 例, 女 18 例, 年齢 $32 \sim 83$ 歳, 平均 $60.7 \pm 9.5$ 歳である. 心筋梗塞発症後 1 力月以上 


\section{表1 患者背景}

\begin{tabular}{lccc}
\hline & $\begin{array}{c}\text { 持続性心室頻拍合併 } \\
(\mathrm{sVT} \text { 群 })\end{array}$ & $\begin{array}{c}\text { 非合併 } \\
\text { (非sVT群) }\end{array}$ & \\
\hline $\mathrm{n}$ & 30 & 136 & \\
年齢(歳) & $58.7 \pm 9.9$ & $61.2 \pm 9.4$ & $\mathrm{~ns}$ \\
男 : 女 & $28: 2$ & $120: 16$ & $\mathrm{~ns}$ \\
LVEF(\%) & $31.2 \pm 14.1$ & $47.6 \pm 12.5$ & $\mathrm{p}<0.01$ \\
記録までの期間(月) & $51.7 \pm 60.8$ & $46.6 \pm 64.4$ & $\mathrm{~ns}$ \\
\hline
\end{tabular}

経た時期に持続性心室頻拍 (sVT) が出現したものは 30 例 (sVT群), 出現しなかったものは136例 (非 sVT群)であった.sVT群と非sVT群との間で年齢 および男女比に有意差は認められなかった(表 1). LVEFは, sVT 群 $(31.2 \pm 14.1 \%)$ では非 $\mathrm{sVT}$ 群 $(47.6 \pm 12.5 \%)$ よりも低下していた $(\mathrm{p}<0.01)$. 心筋 梗塞発症から体表面電位図記録までの期間について は両群間で有意な差は認められなかった。sVT群に おいて心筋梗塞発症からsVT出現までの期間は，1〜 260 力月, 平均 $50.9 \pm 60.4$ 力月であり, 発症後 5 年以 上のものが10例認められた。

追跡調查期間中の心室性不整脈に対する治療とし て, 塩酸アミオダロン投与 16 例, 塩酸アミオダロン 以外の抗不整脈薬 35 例, 植込み型除細動器 6 例, 電 気的焼灼術 6 例，心室瘤切除術 6 例が行われた。

\section{III. 方法}

フクダ電子社製体表面電位図記録装置 VCM-3000 を用いて抗不整脈薬非投与時に洞調律における体表 面 87 単極誘導心電図および標準 12 誘導心電図の同 時記録を行った. 得られた記録より QRST等積分值 図作成, $\mathrm{RT}$ 等時線図作成, 87 誘導における RT dispersion 計測および標準 12 誘導におけるQT dispersion 計測を行った。

QRST 等積分值図上, 正または負の最大積分值を 有する誘導点で正のものを極大，負のものを極小と した。さらにこれらの誘導点と電極間隔が 2 個以上 離れて存在し，かつ周囲より $1 \mu \mathrm{Vsec}$ 以上積分值の 絶対值が大きい誘導点も極大，極小とした，極大， 極小が一対の場合を単一双極子性分布，極大と極小 が合わせて 3 点以上存在する場合を多双極子性分布

\section{とした ${ }^{5), 24)}$.}

VCM-3000を用いて各誘導の T 波の一次微分值を $1 \mathrm{~ms}$ 間隔で計測し，最大值となる時点を RT とした。 一次微分值の最大点の決定が困難な場合には Haws らの方法に従った ${ }^{13)}$. RTの值はすべての誘導にお ける QRS 波の最早期開始点を $0 \mathrm{~ms}$ として表示した. RT dispersion およびQT dispersionについては，さ らにBazett式による心拍数補正を行いR R c dispersionおよびQTc dispersionを算出した。

各評価法における再分極過程不均一性増大の陽性 基準を QRST等積分值図での多双極子性分布， RTc dispersionが180ms 以上，およびQTc dispersionが $80 \mathrm{~ms}$ 以上とした.

追跡調查を最大 72 力月, 平均 $47 \pm 28$ 力月行った. 植込み型除細動器移植術施行例において, VTに対 する作動が確認された場合にはsVT出現とした。 sVTおよび突然死の発生予知について Kaplan-Meier 法, Wilcoxon 検定を用いて $\mathrm{p}<0.05$ の場合を有意差 ありとして検討した。計測值は平均士標準偏差で表 示し，2群間の比較には対応のないt検定を用いて $\mathrm{p}<0.05$ の場合を有意差ありとした．治療法の比較 にはFisherの直接確率計算法を用いて $\mathrm{p}<0.05$ の場 合を有意差ありとした。

\section{IV. 結 果}

\section{SVT 群と非 sVT 群との比較 (図2)}

QRST 等積分值図における多双極子性分布の頻度 はsVT群 $93 \%$ ，非sVT群 $28 \%$ あり，sVT群は非 $\mathrm{sVT}$ 群に比べて高率であった $(\mathrm{p}<0.001)$. RT

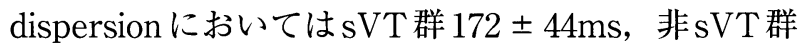
$146 \pm 20 \mathrm{~ms}$ であり，sVT群では非 sVT 群よりも延 長していた $(\mathrm{p}<0.001)$. RTc dispersionにおいても 同様にsVT群 $183 \pm 40 \mathrm{~ms}$, 非 sVT群 $153 \pm 18 \mathrm{~ms}$ と $\mathrm{sVT}$ 群では非 $\mathrm{sVT}$ 群よりも延長していた $(\mathrm{p}<0.001)$.

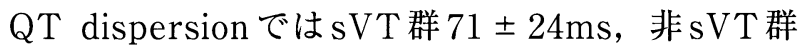
$64 \pm 25 \mathrm{~ms}$ と両群間に有意差は認められなかった。 QTc dispersionにおいても同様にsVT群 $76 \pm 26 \mathrm{ms,}$ 非 sVT群 $67 \pm 26 \mathrm{~ms}$ と両群間に有意差は認められな 
multipolar QRST I-map

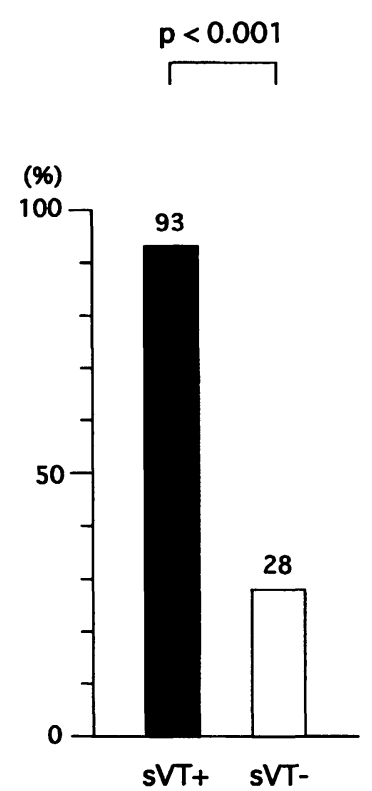

RT dispersion RTc dispersion

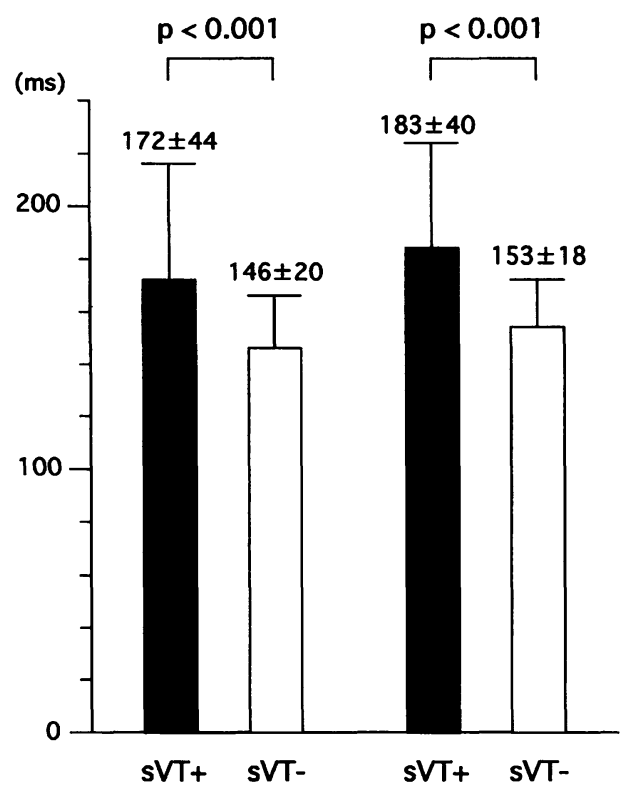

QT dispersion QTc dispersion

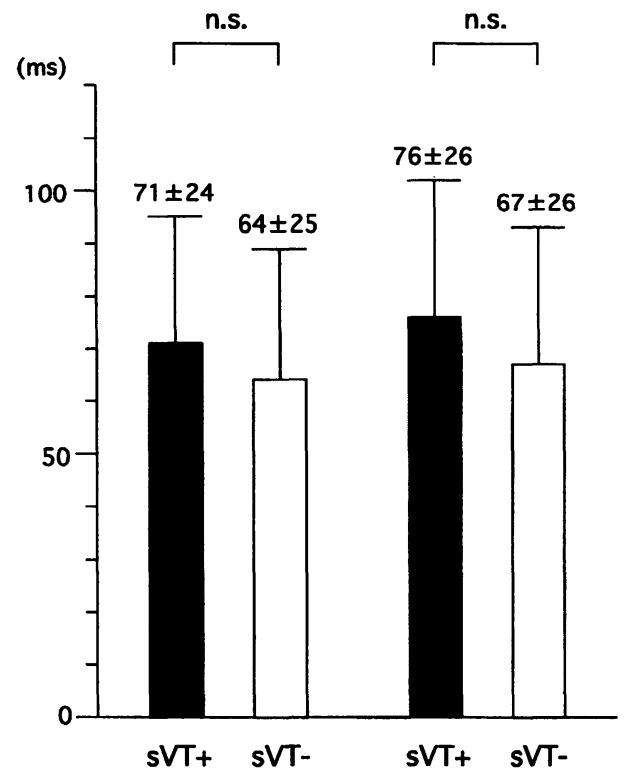

図2 sVT群と非sVT群の比較

multipolar QRST I-map：多双極子性QRST 等積分值図, sVT + : sVT 群, sVT - : 非 $\mathrm{sVT}$ 群
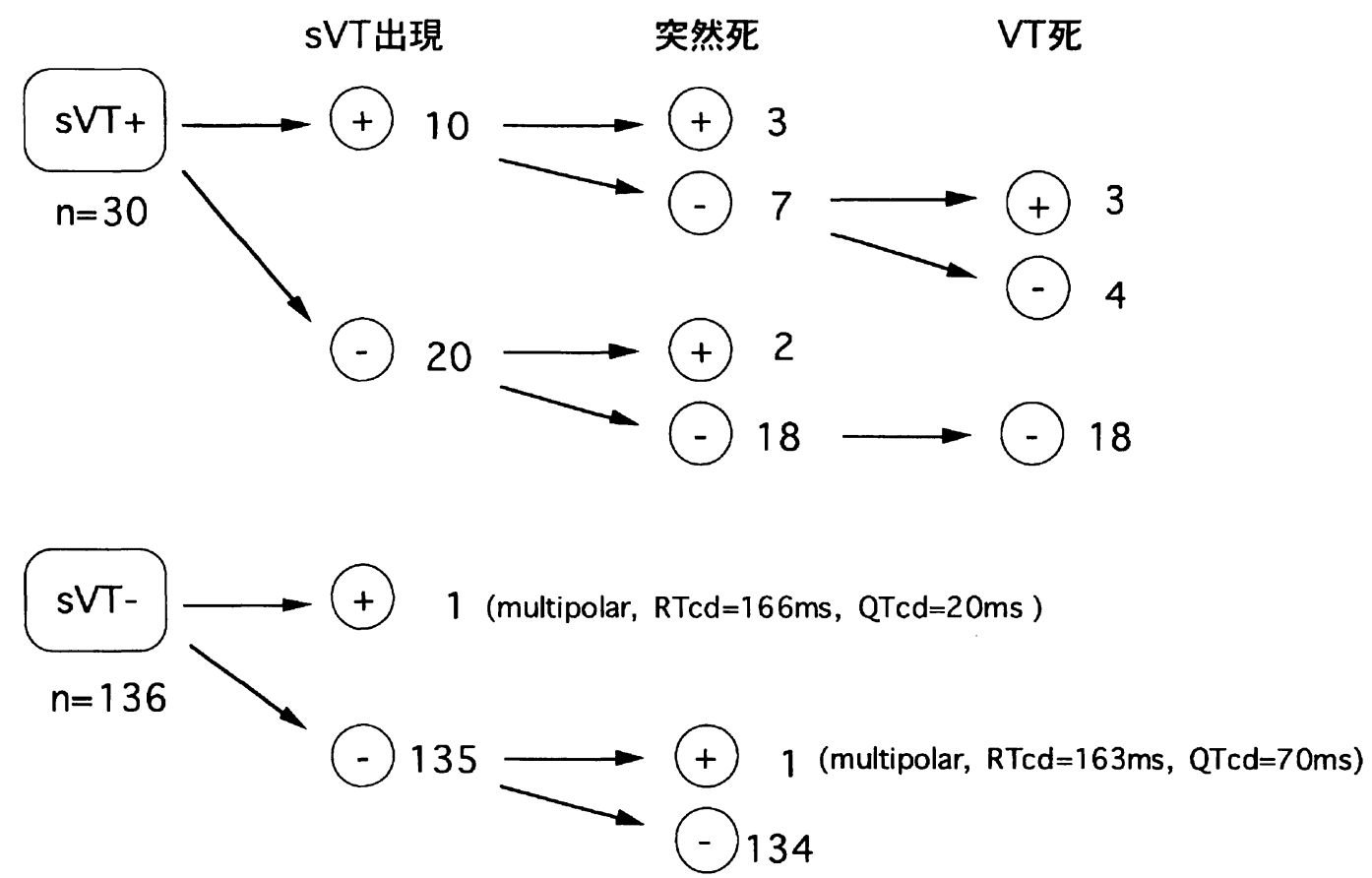

図3 追跡調査結果

sVT + : sVT 群, sVT - : 非sVT群, multipolar：多双極子性分布, RTcd : RTc dispersion, QTcd：

QTc dispersion 
かった。

\section{2. 追跡調查期間の経過}

追跡調査期間中の心事故として sVT 出現は 11 例, 突然死は6例であり，突然死のうち 3 例はsVT 出現 後に不整脈治療を行っていたにもかかわらず突然死 をきたした症例であった(図3).

$\mathrm{sVT}$ 群では追跡調査中 10 例にsVTが再発し，う ち3例ではその後に突然死をきたした。突然死をき たさなかった 7 例中 3 例では難治性心室頻拍が頻発 し，心源性ショックにより死亡した，追跡調查中 sVTが確認されなかった 20 例のうち 2 例では突然死 をきたした。

非 sVT群では経過中新たにsVTが出現したもの が1例，突然死をきたしたものが1例認められた。 両者ともQRST 等積分值図は多双極子性分布を示 L, RTc dispersionは180ms未満であり，かつQTc dispersionは80ms未満であった。

\section{3. 心事故発生予知}

QRST 等積分值図の分布が単一双極子性であった ものは 100 例，多双極子性であったものは66例であっ た. 72 力月後の $\mathrm{sVT}$ または突然死からの累積回避率
は単一双極子性分布で $98.9 \%$ ，多双極子性分布で $78.8 \%$ であり，多双極子性分布では単一双極子性分 布よりも高頻度にsVTまたは突然死をきたしていた $(\mathrm{p}<0.001)$ (図4).

RTc dispersionが $180 \mathrm{~ms}$ 未満のものは 140 例, $180 \mathrm{~ms}$ 以上のものは 26 例であった. 72 力月後の $\mathrm{sVT}$ または突然死からの累積回避率はRTc dispersion

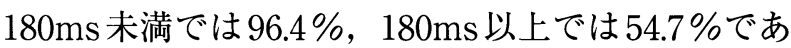
り，180ms 以上のものは $180 \mathrm{~ms}$ 未満よりも高頻度に sVT または突然死をきたしていた $(p<0.001)$.

QTc dispersionが $80 \mathrm{~ms}$ 末満のものは 111 例， $80 \mathrm{~ms}$ 以上のものは55例であった. 72 力月後の sVT または突然死からの累積回避率は，QTc dispersion $80 \mathrm{~ms}$ 未満では $92.9 \%, 80 \mathrm{~ms}$ 以上では $86.1 \% て ゙ あ り ，$ 両者の間に有意差は認められなかった。 $100 \mathrm{~ms}$ 以上 の延長例には経過中にsVT または突然死は出現しな かった。

\section{4. 診断精度}

それぞれの評価法におけるsVT または突然死につ いての診断精度は，QRST 等積分值図では感度 92.9\%(13/14)，特異度65.1\%，正確度67.5\%であり，
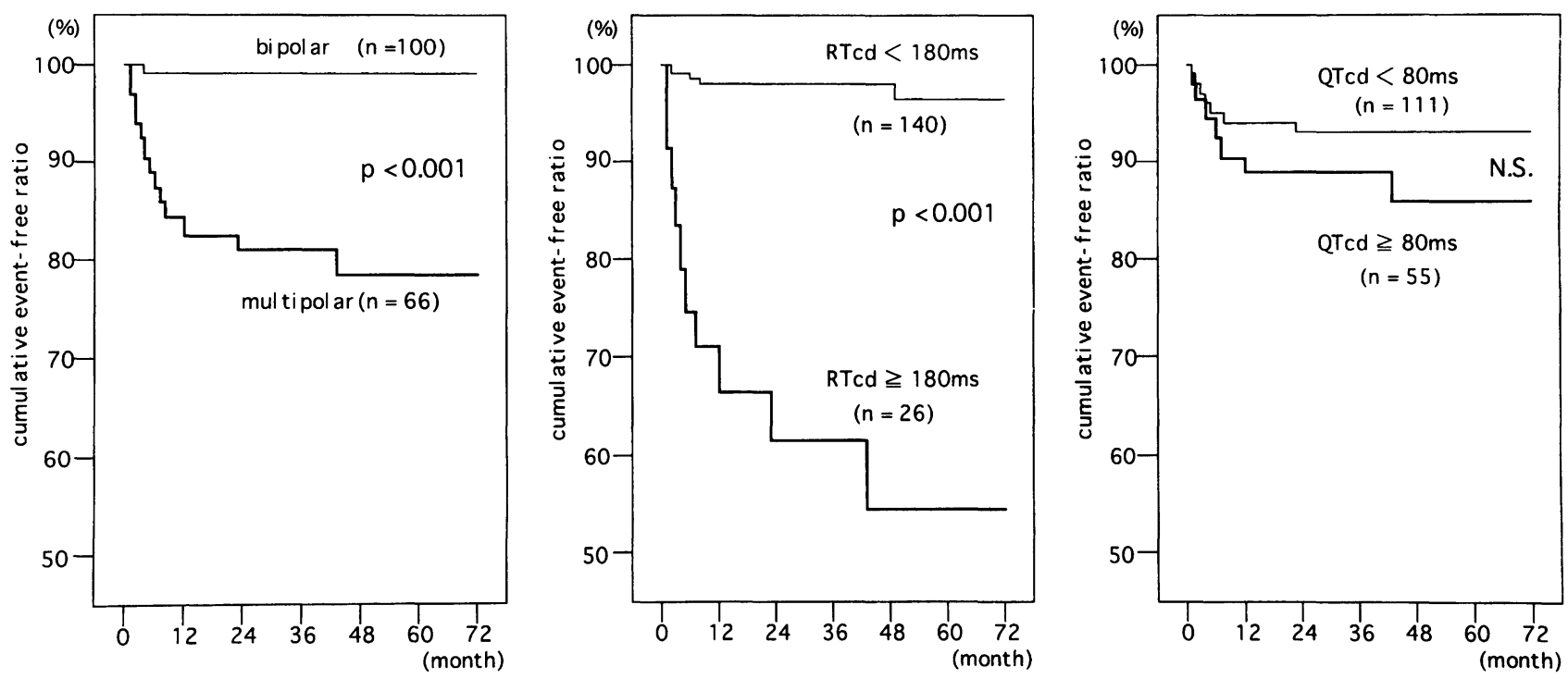

図4＼cjkstart持続性心室頻拍または突然死に関する Kaplan-Meier 法による検討 cumulative event-free ratio：累皘回避率, bipolar：単一双極子性分布, multipolar：多双極子性分布, RTcd : RTc dispersion, QTcd : QTc dispersion 


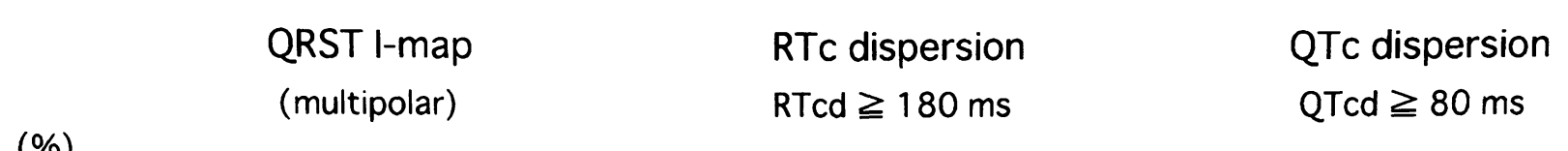

(\%)

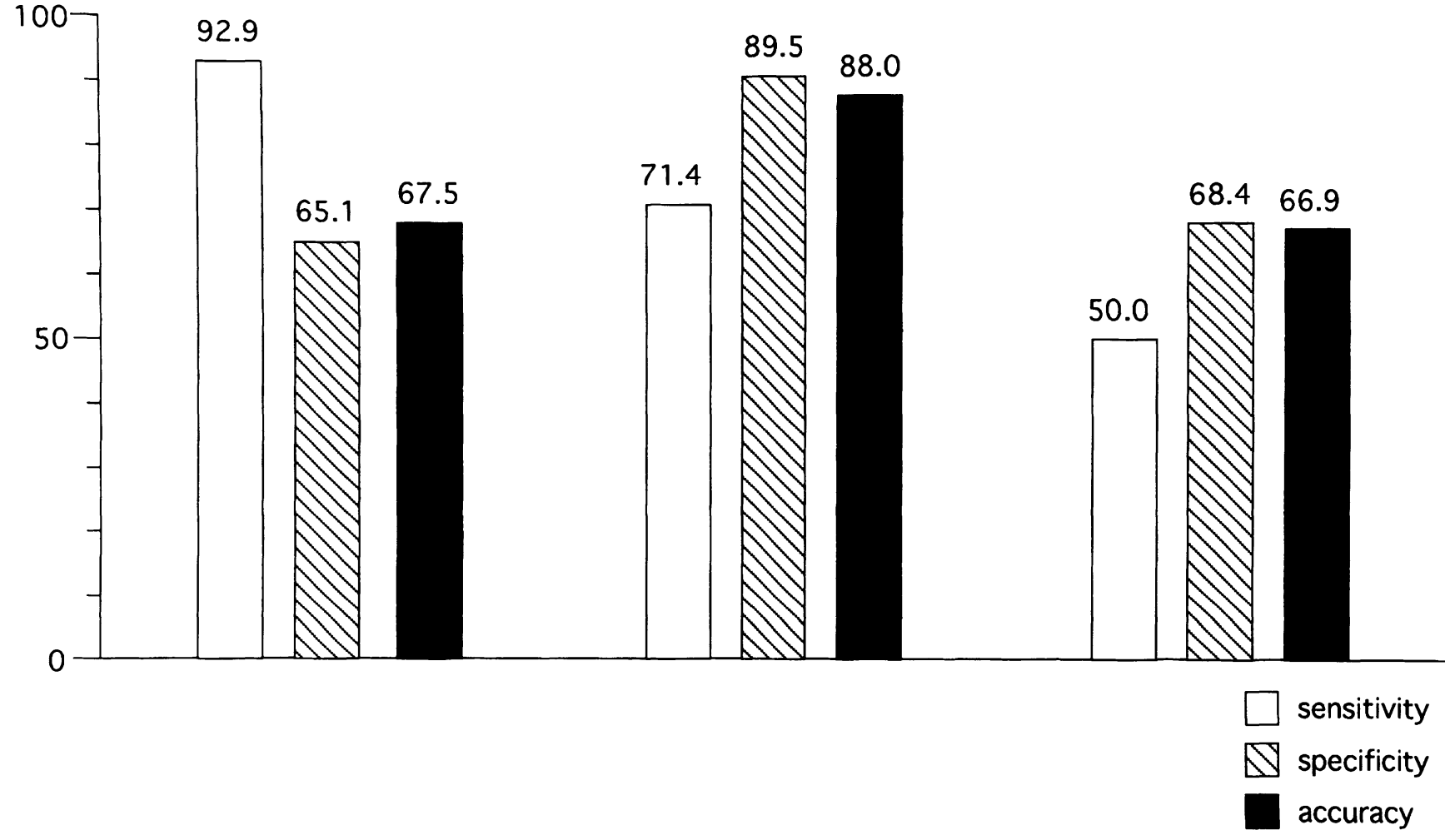

図5＼cjkstart持続性心室頻拍または突然死に関する診断精度

QRST I-map：QRST 等積分值図, multipolar：多双極子性分布, RTcd：RTc dispersion, QTcd：QTc dispersion, sensitivity : 感度, specificity : 特異度, accuracy : 正確度

とくに感度が良好であった(図5)，RTc dispersion では感度 $71.4 \%$ ，特異度 $89.5 \% ，$ 正確度 $88.0 \%$ であ り，特異度および正確度が良好であった。QTc dispersionでは感度 $50.0 \%$, 特異度 $68.4 \%$, 正確度 $66.9 \%$ あ゙あった。

\section{5. 再分極過程評価法の組み合わせ}

QRST 等積分值図とRTc dispersion とを組み合わ せた Kaplan-Meier 法によるsVTまたは突然死から の累積回避率の検討を図6に示す，QRST等積分值 図が多双極子性分布を示しかつRTc dispersionが $180 \mathrm{~ms}$ 以上に延長している場合は，72 月月後の累積 回避率が $44.7 \%$ あ゙あり，それ以外の場合 (93.3\%， $98.9 \%, 100 \%)$ に比べて予後が悪かった $(\mathrm{p}<0.0001)$. ハイリスク群の陽性基準を多双極子性分布かつ RTc dispersion 180ms 以上とすると感度 $71.4 \%$ ，特異度 $94.1 \%$ ，正確度 $92.3 \%$ ありり，特異度および正確度 はすべての単独の評価法よりも良好であった。

\section{6. 治療法の比較 (表2)}

QRST 等積分值図の分布が多双極子性を示した群 と単一双極子性を示した群との間の心室性不整脈に 対する治療法を比較すると，塩酸アミオダロン，塩 酸アミオダロン以外の抗不整脈薬，植込み型除細動 器, 電気的焼灼術および心室瘤切除術のすべての治 療法において多双極子性を示した群のほうが高率で あったＲTc dispersionについても $180 \mathrm{~ms}$ 以上の群 は $180 \mathrm{~ms}$ 未満の群よりすべての治療法がより高率に 行われていた. 


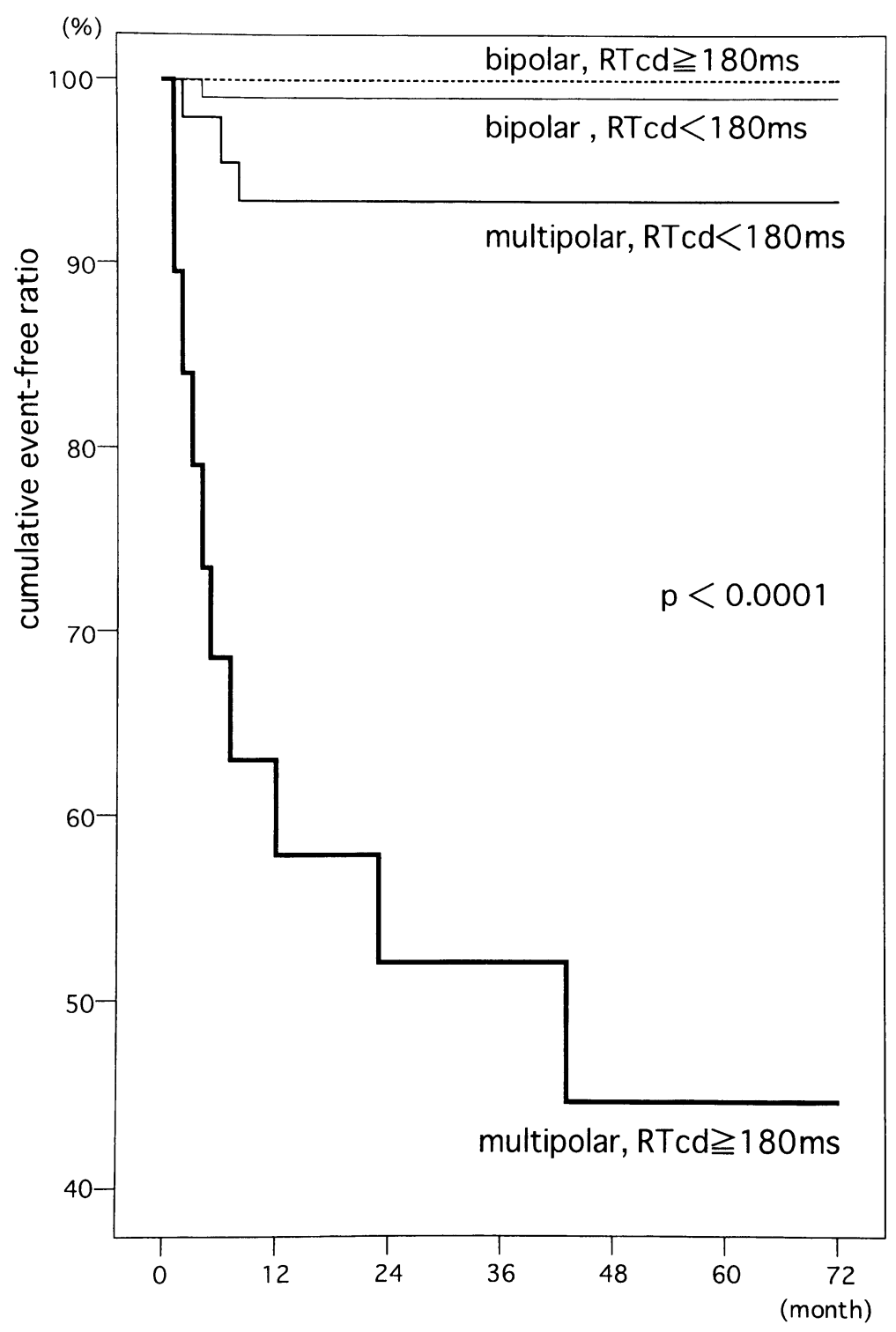

図6 QRST 等積分值図とRTc dispersionの組み合わせによる検討

cumulative event-free ratio: 累積回避率, bipolar：単一双極子性分布, multipolar : 多双 極子性分布, RTcd：RTc dispersion

\section{V. 考案}

心室再分極過程における不均一性増大は, リエン トリーの成立を容易にして心室頻拍および心室細動 の発生，維持に関与することが知られている．体表 面QRST 等積分值図は再分極についての視覚的な評 価法として確立された検査法である。心筋梗塞, QT 延長症候群および肥大型心筋症などにおいては
多双極子性分布と心室頻脈性不整脈との間の関連性 が報告されている5), 24) 28). とくに陳旧性心筋梗塞に おいては，多双極子性分布は持続性心室頻拍とは関 連があるが非持続性心室頻拍とは関連がないこと， および多双極子性分布を示す症例では心室ペーシン グにより高率に持続性単形性心室頻拍が誘発される ことより，多双極子性分布を示す場合は致死性不整 脈を合併する危険性が高いことが知られている ${ }^{5), 24)}$. 
表2 治療法

\begin{tabular}{|c|c|c|c|c|c|c|}
\hline & $\begin{array}{c}\text { 多双極子性 } \\
(\%)\end{array}$ & $\begin{array}{c}\begin{array}{c}\text { 単一双極子性 } \\
(\%)\end{array} \\
\end{array}$ & $p$ & $\begin{array}{c}\mathrm{RTcd} \geqq 180 \mathrm{~ms} \\
(\%)\end{array}$ & $\begin{array}{c}\text { RTcd }<180 \mathrm{~ms} \\
(\%)\end{array}$ & $p$ \\
\hline$n$ & 66 & 100 & & 26 & 140 & \\
\hline AMD $(n=16)$ & $14(21.2)$ & $2(2.0)$ & $<0.001$ & $12(46.2)$ & $4(2.9)$ & $<0.001$ \\
\hline $\begin{array}{c}\text { 抗不整脈萝 (AMD以外) } \\
\quad(n=35)\end{array}$ & $23(34.8)$ & $12(12.0)$ & $<0.001$ & $12(46.2)$ & $23(16.4)$ & $<0.01$ \\
\hline $\operatorname{ICD}(n=6)$ & $6(9.1)$ & 0 & $<0.01$ & $5(19.2)$ & $1(0.7)$ & $<0.01$ \\
\hline 電気的燒灼術 $(n=6)$ & $6(9.1)$ & 0 & $<0.01$ & $4(15.4)$ & $2(1.4)$ & $<0.01$ \\
\hline 心室瘤切除術 $(n=6)$ & $6(9.1)$ & 0 & $<0.01$ & $3(11.5)$ & $3(2.1)$ & $<0.05$ \\
\hline
\end{tabular}

RTcd: RTC dispersion、AMD:アミオタロン、ICD: 植込型除細動器

ただし，これらの検討はすべて後ろ向き検討である. 本研究では陳旧性心筋梗塞において初めて前向き検 討を行い，QRST等積分值図が多双極子性分布を示 す場合は単一双極子性分布を示す場合に比べて持続 性心室頻拍および突然死をきたす危険性が高いこと を明らかにし，後ろ向き検討の結果を裏付けること ができた．感度が $92.9 \%$ と良好なことおよび非 $\mathrm{sVT}$ 群において多双極子性分布を示した症例に特異的に 新たな SVT出現および突然死が認められたことか ら，陳旧性心筋梗塞において多双極子性分布を示す 場合には心室頻拍および心室細動の既往がない場合 でもハイリスク群として扱うべきと考えられた。

RTc dispersionは再分極過程終了時点のばらつき から再分極過程不均一性を評価する方法であり，臨 床的有用性が報告されている ${ }^{4), 29 ， 30)}$ ．本研究では以 前，我々が報告した前壁梗塞における持続性心室頻 拍非合併例の平均値 +標準偏差の值をもとに cut off 值を $180 \mathrm{~ms}$ として検討した ${ }^{4)}$.この結果, RTc dispersion 延長例は非延長例と比較して持続性心室 頻拍および突然死の危険性が高いことが示唆され た．とくに特異度が $89.5 \%$ と高く，QRST 等積分值 図で感度が高いことと対照的であった。さらに QRST 等積分值図と RTc dispersion を組み合わせる 320
ことにより，QRST等積分值図が多双極子性分布を 示し，かつRTc dispersionが180ms 以上に延長して いる場合には極めて予後が悪いことが示唆された. 以上，陳旧性心筋梗塞における致死性不整脈の発生 予知に体表面電位図による 2 種類の検査法の組み合 わせが有用であった.

QTc dispersionは健常者では30～60ms といわれ ており，陳旧性心筋梗塞では健常者より延長してい ることが知られている $\left.{ }^{31}, 23\right), 31$. 陳旧性心筋梗塞にお けるQTc dispersionのcut off值については研究者に より異なる、QTc dispersionの場合，一定の值まで はcut off值の増加とともに感度は低下し特異度は上 昇すると考えられる．本研究では $100 \mathrm{~ms}$ 以上の高值 を示す症例に心事故が認められなかったことおよび Perkiomakiらの報告を参考にして, cut off 值を 80ms として検討した ${ }^{3)}$.

QTc dispersionでは致死性不整脈発生予知に関す る有用性を示唆する所見は認められなかったＱTc dispersionには方法論的に T波終末決定の再現性， 測定者間の誤差, 限られた誘導数および誘導部位に よる情報量の限界，肢誘導の取扱い，全誘導同時記 録の困難性，体表面から得られる心表面情報の限界， およびT波が対側心内膜面の電位も反映しているこ 



dispersionの臨床的有用性に対して否定的な報告が みられるようになり，本研究においてもこれを支持 する結果が得られた ${ }^{7), 23)}$.

調查期間中の $\mathrm{sVT}$ の治療法には変遷があり, 初期 には電気生理学的薬効評価法による塩酸アミオダロ ンを含む種々の抗不整脈薬, 電気的焼灼術, 心室瘤 切除術および植込み型除細動器などが単独で，また は無効の場合他の治療法が追加して行われた。その 後塩酸アミオダロン投与および植込み型除細動器が もっぱら施行されるようになった．治療法が統一さ れていないことは本研究の限界と考えられた。

sVTに対する治療はQRST 等積分值図の分布が単 一双極子性よりも多双極子性の場合，およびRTc dispersionが180ms 未満よりも180ms 以上の場合に それぞれ高率に行われていた。このことはsVT群は 非 sVT群に比べて多双極子性分布の頻度が高く，か つRTc dispersionが延長していることから当然のこ とと考えられた。重要なことは, 非 sVT群のうち $\mathrm{sVT}$ または突然死をきたした 2 例ともに多双極子性 分布を示していたことである. 非 SVT群の症例にお いてもQRST等積分值図が多双極子性分布を示した 場合には, ホルター心電図, LP, 電気生理学的検査 などの検査を行い塩酸アミオダロンおよび植込み型 除細動器の適応について検討すべきと考えられた。

体表面電位図では解剖学的に心室下壁を直接反映 する誘導を得ることが困難である。このため前壁梗 塞における心電情報と比べて下壁梗塞における心電 情報は限られており，sVTに対する診断精度が劣る ことが知られている ${ }^{5)}$. 本研究では梗塞部位の混在 を避け，前壁梗塞に限定して検討を行った。本研究 にて前壁梗塞におけるQRST等積分值図およびRTc dispersionの臨床的有用性が確認されたことから， 今後は拡張型心筋症など他疾患についても前向き調 查によるQRST等積分值図およびRTc dispersionの 有用性を検討すべきと考えられた。

\section{[文献〕}

1 ) Kuchar DL, Thorburn CW, Sammel NL : Late potentials detected after myocardial infarction. natural history and prognostic significance. Circulation, $1986 ; 74: 1280 \sim$ 1289

2 ) Pye M, Quinn AC, Cobbe SM : QT interval dispersion. a non-invasive marker of susceptibility to arrhythmia in patients with sustained ventricular arrhythmias? $\mathrm{Br}$ Heart J, $1994 ; 71: 511 \sim 514$

3 ) Perkiomaki JS, Koistinen MJ, Yli-Mayry S, Huikuri HV : Dispersion of QT interval in patients with and without susceptibility to ventricular tachyarrhythmias after previous myocardial infarction. J Am Coll Cardiol, 1995 ; $26: 174 \sim 179$

4 ) Nirei $T$, Kasanuki H : Recovery time dispersion measured by body surface mapping. noninvasive method of assessing vulnerability to ventricular tachyarrhythmias. J Electrocardiol, $2001 ; 34: 127 \sim 133$

5 ) Nirei T, Kasanuki H, Toyoshima Y, Hosoda S : Clinical significance of body surface QRST isointegral map concerning sustained ventricular tachycardia in patients with old myocardial infarction. Advanced in body surface mapping and high resolution ECG : Yasui S, Abildskov JA, Yamada K, Harumi K ed, Life Medicom, Nagoya, $1995 ; 127 \sim 136$

6 ) Rosenbaum DS, Jackson LE, Smith JM, Garan H, Ruskin JN, Cohen RJ : Electrical alternans and vulnerability to ventricular arrhythmias. N Engl J Med, 1994 ; 330 : 235 241

7 ) Hohnloser SH, Klingenheben T, Li Y, Zabel M, Peetermans J, Cohen RJ : T wave alternans as a predictor of recurrent ventricular tachyarrhythmias in ICD recipients. prospective comparison with conventional risk markers. J Cardiovasc Electrophysiol, $1998 ; 9: 1258 \sim 1268$

8 ) Bigger JT, Weld FM, Rolnitzky LM : Prevalence, characteristics and significance of ventricular tachycardia (three or more complexes) detected with ambulatory electrocardiographic recording in the late hospital phase of myocardial infarction. Am J Cardiol, $1981 ; 48: 815 \sim 823$

9 ) Bigger JT, Fleiss JL, Kleiger R, Miller JP, Rolnitzky LM : The relationship among ventricular arrhythmias, left ventricular dysfunction, and mortality in the 2 years after myocardial infarction. Circulation, 1984 ; 69 : 250 258

10) Statters D, Malik M, Ward DE, Camm AJ : QT dispersion. problems of methodolody and clinical significance. J Cardiovasc Electrophysiol, 1994 ; 5 : 672 685 
11) Wyatt RF, Burgess MJ, Evans AK, Lux RL, Abildskov JA, Tsutsumi $\mathrm{T}$ : Estimation of ventricular transmembrane action potential durations and repolarization times from unipolar electrograms. Am J Cardiol, $1981 ; 47: 488$

12) Millar CK, Kralios FA, Lux RL : Correlation between refractory periods and activation-recovery intervals from electrograms. effects of rate and adrenergic interventions. Circulation, $1985 ; 72: 1372 \sim 1379$

13) Haws AW, Lux RL : Correlation in vivo transmembrane action potential durations and activation-recovery intervals from electrograms. effects of interventions that alter repolarization tome. Circulation, $1990 ; 81: 281 \sim$ 288

14) 八巻通安, 柴田健彦, 池野栄一郎, 近藤恒博, 久保田功, 友池仁暢：体表面 activation-recovery interval 計測によ る心筋局所活動電位持続時間 (APD) 推定の妥当性. Jpn Circ J, 1994 ; 58 (Suppl. I ) : 449

15) Kamide S, Nagai N, Yamaguchi T, Mori S, Matsubara Y, Noba M, Ishikawa M, Abo Y, Nakano H, Chikamatsu $\mathrm{H}$, Hishida H, Watanabe Y : Correlation between epicardial ARI and body surface ARI map in patients with ischemic heart disease. Jpn Circ J, 1996 ; 60 : 402 403

16) Lepeschkin E, Surawicz B : The measurement of the Q$\mathrm{T}$ interval of the electrocardiogram. Circulation, $1952 ; 6$ : 378 388

17) Higham PD, Campbell RWF : QT dispersion. Br Heart J, $1994 ; 71: 508 \sim 510$

18) Hirai M, Tsubo N, Hayashi H, Ito M, Inden $Y$, Hirayama H, Ito $T$, Yanagawa $T$, Sano H, Kondo T, Tomita Y, Todoroki H, Tsuda M, Saito H : Body surface distribution of abnormal low QRST areas in patients with Wolff-Parkinson-White syndrome. evidence for continuation of repolarization abnormalities before and after catheter ablation. Circulation, $1993 ; 88: 2674 \sim$ 2684

19) Dambrink JH, SippensGroenewegen A, van Gilst W, Peels KH, Grimbergen CA, Kingma JH : Association of left ventricular remodeling and nonuniform electrical recovery expressed by nondipolar QRST integral map patterns in survivors of a first anterior myocardial infarction. Circulation, $1995 ; 92: 300 \sim 310$

20) De Ambroggi L, Aime E, Ceriotti C, Rovida M, Negroni $\mathrm{S}$ : Mapping of ventricular repolarization potentials in patients with arrhythmogenic right ventricular dysplasia. principal component analysis of ST-T waves. Circulation, $1997 ; 96: 4314 \sim 4318$

21) Nirei T, Kasanuki H, Ohnishi S, Tamaki A, Toyoshima Y, Hosoda S : Cardiac memory in patients with intermittent Wolff-Parkinson- White syndrome. J Electrocardiol, $1997 ; 30: 323 \sim 329$

22) Glancy JM, Garratt CJ, Woods KL, de Bono DP : QT dispersion and mortality after myocardial infarction. Lancet, 1995 ; 345 : 945 948

23) Zabel M, Klingenheben T, Franz MR, Hohnloser SH : Assessment of QT dispersion for prediction of mortality or arrhythmic events after myocardial infarction. results of a prospective, long-term follow-up study. Circulation, $1998 ; 97: 2543 \sim 2550$

24）仁禮 隆，笠貫 宏，大西 哲，豊島ゆかり，細田瑳一： 心室頻拍易誘発性に関する QRST isointegral mapの意 義. 心電図, $1994 ； 14 ： 152 \sim 159$

25) Gardner MJ, Montague TJ, Armstrong CS, Horacek BM, Smith ER : Vulnerability to ventricular arrhythmia. assessment by mapping of body surface potential. Circulation, $1986 ; 73: 684 \sim 692$

26）仁禮 隆, 笠貫 宏, 細田瑳一：急性心筋梗塞における QRST isointegral mapの検討一重症心室性不整脈との関 連について一. 心電図, $1992 ; 12: 80 \sim 87$

27 ）仁僼 隆：先天性 QT 延長症候群. 体表面心臓電位図 · 体表面心臓微小電位の臨床 : 安井昭二編, ライフメディ コム出版部, 名古屋, $1994 ; 211 \sim 215$

28）篠田尚克, 仁禮 隆, 大西 哲, 笠貫 宏: 肥大型心筋症 における再分極異常と持続性心室頻拍との関連について の検討. 体表面 QRST 等積分值図を用いて. 不整脈, $1998 ; 14: 175$

29) Shimizu W, Kamakura S, Ohe T, Kurita T, Takai H, Aihara N, Shimomura K : Diagnostic value of recovery time measured by body surface mapping in patients with congenital long QT syndrome. Am J Cardiol, 1994 ; $74: 780 \sim 785$

30) Aiba T, Inagaki M, Shimizu W, Matsuo K, Taguchi A, Suyama K, Kurita T, Aihara N, Sunagawa K, Kamakura $\mathrm{S}$ : Recovery time dispersion from 87-lead body surface potential mapping as a predictor of sistained ventricular tachycardia in patients with idiopathic dilated cardiomyopathy. J Cardiovasc Electrophysiol, $2000 ; 11$ : 968 $\sim 974$

31) Malik M, Batchvarov VN : Measurement, interpretation and clinical potential of QT dispersion. J Am Coll Cardiol, $2000 ; 36: 1749 \sim 1766$

32) Ikeno E, Kubota I, Kondo T, Shibata T, Yamaki M, Tomoike H : Diagnostic usefulness of activationrecovery interval for reciprocal ECG changes. J Electrocardiol, $1995 ; 28: 237 \sim 243$

33) Wang L : QT dispersion from body surface ECG does not reflect the spatial dispersion of ventricular repolarization in sheep. PACE, $2000 ; 23: 359 \sim 364$ 